\title{
IMPLEMENTASI ALGORITMA REGRESI LINEAR BERGANDA UNTUK MEMPREDIKSI PRODUKSI PADI DI KABUPATEN BANTUL
}

\author{
${ }^{1)}$ Ervan Triyanto, ${ }^{2}$ Heri Sismoro, ${ }^{3)}$ Arif Dwi Laksito \\ Informatika, Ilmu Komputer, Universitas Amikom Yogyakarta \\ Jl. Ring Road Utara, Condong Catur, Depok, Sleman, Yogyakarta \\ E-mail :ervan.triyanto@students.amikom.ac.id,herisismoro@amikom.ac.id,arif.laksito@amikom.ac.id
}

\begin{abstract}
ABSTRAK
Ketersediaan pangan yang cukup dan merata merupakan salah satu pilar perwujudan ketahanan pangan. Setiap tahunnya produksi padi di Kabupaten Bantul selalu berubah-ubah. Metode Regresi Linear Berganda adalah metode peramalan yang menggunakan lebih dari dua faktor yang dapat mempengaruhi hasil sehingga dapat menemukan hasil yang maksimal. Dengan metode Regresi Linear Berganda ini di dapatkan mean absolute deviation (MAD) 0,101 dengan data pelatihan dari tahun $2009-2017$. Persamaan Regresi Linear berganda yang didapatkan yaitu $\mathrm{Y}=8307,561443282+5,9294543706657 x_{1}+118,28063200866 x_{2}+175,71009241484 x_{3}$
\end{abstract}

Kata Kunci: Regresi linear berganda, Prediksi produksi padi.

\section{ABSTRACT}

Sufficient and equitable food availability is one of the pillars of the realization of food security. Every year rice production in Bantul Regency is always changing. Multiple Linear Regression Method is a forecasting method that uses more than two factors that can influence the results so that it can find maximum results. With this method of Multiple Linear Regression, get the mean absolute deviation (MAD) 0.101 with training data from 2009 - 2017. Multiple linear regression equations obtained were $Y=8307,561443282+5,9294543706657 x_{1}+$ $118,28063200866 x_{2}+175,71009241484 x_{3}$.

Keywords: Multiple linear regression, Prediction of rice production

\section{PENDAHULUAN}

Ketersediaan pangan yang cukup dan merata merupakan salah satu pilar perwujudan ketahanan pangan. Salah satu inti pokok dari ketahanan pangan adalah tersedianya makanan pokok bagi masyarakat. Salah satu makanan pokok yang dikonsumsi adalah nasi. Nasi adalah hasil dari pengolahan hasil pertanian yaitu padi. Padi (Oryza Sativa) adalah salah satu dari jenis tanaman pertanian yang bernilai ekonomis, di Bantul sendiri padi tergolong sebagai tanaman pangan pokok yang banyak dibudidayakan.

Kabupaten Bantul sendiri merupakan salah satu kabupaten di Provinsi Daerah Istimewa Yogyakarta. Kabupaten Bantul memiliki luas wilayah 50.810 hektare, dengan pemanfaatan lahan pertanian berupa sawah sebesar 15.183 ha dan lahan bukan sawah sebesar 12.742 ha. Luas lahan sawah yang cukup luas ini dimanfaatkan untuk pertanian padi. Produksi padi di Bantul pada tahun 2014 sebesar 192.847 ton, pada tahun 2015 sebesar 199.141 ton, dan pada tahun 2016 sebesar 180.593 ton.

Karena produksi padi di kabupaten Bantul setiap tahun selalu berubah - ubah, maka sebuah prediksi perlu dilakukan untuk mengetahui gambaran masa depan apakah hasil produksi padi di kabupaten Bantul akan mengalami kenaikan ataupun penurunan. Hasil prediksi ini dapat digunakan sebagai tolak ukur untuk mengetahui ketahanan pangan di kabupaten bantul khususnya padi. Penelitian ini memanfaatkan data panen atau produksi padi di dinas pertanian kabupaten Bantul sebagai data acuan untuk melakukan prediksi hasil panen padi di kabupaten bantul. Selain itu prediksi ini juga mempertimbangkan beberapa faktor yang dapat mempengaruhi hasil prodiksi yang berupa luas lahan, curah hujan, serangan 
hama, hasil produksi sebelumnya, serta pengetahuan petani tantang penanaman padi. Untuk melakukan prediksi tentunya harus menggunakan sebuah algoritma, salah satu algoritma untuk melakukan prediksi ini dengan menggunakan Algoritma Regresi Linear Berganda. Algoritma Regresi Linear Berganda merupakan salah satu teknik analisis data yang sering digunakan untuk mengkaji hubungan antar beberapa variabel dan meramal satu variable [1].

Penelitian yang akan dilakukkan ini menggunakan Algoritma Regresi Linear Berganda karena metode ini sesuai dengan studi kasus yang sedang diteliti. Dalam penelitian ini akan menggunakan data dari tahun 2009 - 2017 yang berasal dari Dinas Pertanian dan Kelautan kabupaten Bantul. Sistem prediksi ini digunakan untuk memprediksi hasil produksi padi dengan menggunakan Algoritma Regresi Linear Berganda.

Terdapat berbagai penelitian yang berkaitan dengan prediksi dengan metode ini diantaranya penelitian Anisa Romandoni yang berjudul Penerapan Metode Regresi Linear Berganda untuk Prediksi Hasil Panen Jagung. Dalam penelitian ini digunakan 3 faktor yang mempengaruhi hasil panen dengan menggunakan metode regresi linear berganda untuk melakukkan prediksi. Hasil melalui pengujian MAPE (Mean Absolute Percentage Error) adalah $10 \%$ yang berarti prediksi hasil panen pada kategori sangat baik [2]. Sedangkan menurut Nur Setyo Utomo dalam penelitiannya, metode Regresi Linear Berganda dapat digunakan untuk memprediksi kelayakan operasional mesin rivet produksi [3]. Farizal juga melakukan penelitian dengan metode Regresi Linear Berganda untuk memprediksi konsumsi bahan bakar jenis premium dan menghasilkan tingkat kesalahan $1.05 \%$ terhadap realitas yang terjadi di tahun 2013 [4].

Dari beberapa penelitian tersebut disimpulkan bahwa metode Regresi Linear Berganda dapat digunakan untuk meprediksi sesuatu di masa depan dengan menggunakan lebih dari 2 faktor atau variabel yang memiliki pengaruh terhadap apa yang akan diprediksi.

\section{Data Mining}

Data mining adalah salah satu proses yang menggunakan teknik statistik, matematika, kecerdasan buatan dan machine learning untuk mengetraksi dan mengidentifikasi informasi yang bermanfaat dan pengetahuan yang terkait dari berbagai database besar [5].

Menurut Gartner Group data mining adalah suatu proses menemukan hubungan yang berarti, pola dan kecenderungan dengan memeriksa dalam sekumpulan besar data yang tersimpan dalam penyimpanan dengan menggunakan teknik pengenalan pola seperti teknik statistik dan matematika [6].

Data mining dibagi menjadi beberapa kelompok berdasarkan tugas yang dapat dilakukan, yaitu [6]:

1. Deskripsi

2. Estimasi

3. Prediksi

4. Klasifikasi

5. Pengklusteran

6. Asosiasi

\section{Prediksi}

Prediksi adalah suatu proses memperkirakan secara sistematis tentang sesuatu yang paling mungkin terjadi di masa depan berdasarkan informasi masa lalu dan sekarang yang dimiliki, agar kesalahannya (selisih antara sesuatu yang terjadi dengan hasil perkiraan) dapat diperkecil. Prediksi tidak harus memberikan jawaban secara pasti 
kejadian yang akan terjadi, melainkan berusaha untuk mencari jawaban sedekat mungkin yang akan terjadi [7]. Peramalan yang baik merupakan peramalan yang dilakukan dengan mengikuti langkah langkah atau prosedur yang baik. Pada dasarnya ada tiga langkah peramalan yang penting, yaitu [8]:

1. Menganalisa data masa lalu.

2. Menentukan metode yang dipergunakan.

3. Memproyeksikan data yang lalu dengan menggunakan metode yang dipergunakan dan mempertimbangkan adanya beberapa faktor perubahan.

\section{Regresi Linear Berganda}

Regresi linier berganda adalah analisis regresi yang menjelaskan hubungan antara peubah respon (variabel dependen) dengan faktor-faktor yang mempengaruhi lebih dari satu prediktor (variabel independen) [9]. Ketika suatu hasil/keluaran,atau kelas berupa numerik, dan semua atribut adalah numerik, regresi linear adalah teknik yang tepat untuk menyelesaikan.

Ini adalah metode pokok di dalam ilmu statistik. Gunanya adalah untuk mengekspresikan kelas sebagai kombinasi linear dari atribut, dengan bobot yang telah di tentukan, dengan rumus sebagai berikut:

$$
Y=a+b 1 X 1+b 2 X 2+\cdots+b n X n
$$

Di mana Y adalah kelas; X1, X2, ..., Xn adalah nilai atribut; dan a, b1, ..., bn adalah bobot. Bobot dihitung dari data sampel.

Dimana:

$Y=$ Variabel tidak bebas (nilai yang diprediksikan)

$X=$ Variabel bebas

$a=$ Konstanta (nilai $Y$ apabila $X 1, X 2 \ldots X n=$ 0)

$b=$ Koefisien regresi (nilai peningkatan ataupun penurunan)

Dimana nilai $a, b 1, b 2 \ldots$ bn dapat dihitung dengan metode persamaan normal yaitu :

$$
\begin{aligned}
& \sum Y=a_{n}+b_{1} \sum X_{1}+b_{2} \sum X_{2} \\
& \sum X_{1} Y=a \sum X_{1}+b_{1} \sum X_{1} X_{2}+b_{2} \sum X_{1} X_{2} \\
& \quad \sum X_{2} Y=a \sum X_{2}+b_{1} \sum X_{1} X_{2}+b_{2} \sum X_{2}
\end{aligned}
$$

Selain dihitung dengan persamaan normal diatas, nilai $1, \mathrm{~b} 1, \mathrm{~b} 2 \ldots$ bn dapat juga dihitung dengan metode kuadran terkecil, yaitu:

$$
\begin{aligned}
b_{1} & =\frac{\left(\Sigma X_{2}^{2}\right)\left(\Sigma X_{1} y\right)-\left(\Sigma X_{2} y\right)\left(\Sigma X_{1} X_{2}\right)}{\left(\Sigma X_{1}^{2}\right)\left(\Sigma X_{2}^{2}\right)-\left(\Sigma X_{1} X_{2}\right)^{2}} \\
b_{2} & =\frac{\left(\Sigma X_{1}^{2}\right)\left(\Sigma X_{2} y\right)-\left(\Sigma X_{1} y\right)\left(\Sigma X_{1} X_{2}\right)}{\left(\Sigma X_{1}^{2}\right)\left(\Sigma X_{2}^{2}\right)-\left(\Sigma X_{1} X_{2}\right)^{2}} \\
a & =\frac{\Sigma Y-\left(b_{1} \Sigma X_{1}\right)-\left(b_{2} \Sigma X_{2}\right)}{n}
\end{aligned}
$$

Dimana:

$\Sigma X_{1}^{2}=\Sigma X_{1}^{2}-\frac{\left(\Sigma X_{1}\right)^{2}}{n}$

$\Sigma X_{2}^{2}=\Sigma X_{2}^{2}-\frac{\left(\Sigma X_{2}\right)^{2}}{n}$

$\Sigma X_{1} X_{2}=\Sigma X_{1} X_{2}-\frac{\left(\Sigma X_{1}\right)\left(\Sigma X_{2}\right)}{n}$

$\Sigma X_{1} \mathrm{Y}=\Sigma X_{1} \mathrm{Y}-\frac{\left(\Sigma X_{1}\right)(\Sigma \mathrm{Y})}{n}$

$\Sigma X^{2} Y=\Sigma X^{1} Y-\frac{\left(\Sigma X^{2}\right)(\Sigma Y)}{n}$

$\Sigma Y^{2}=\Sigma Y^{2}-\frac{(\Sigma Y)^{2}}{n}$

Ketika variable bebas lebih dari 2, nilai konstanta dan koefisien regresi setiap variabel bebas dapat diperoleh dengan menggunakan matriks determinan [10]. Contohnya adalah ketika terdapat 3 persamaan dengan 3 variabel yang tidak diketahui nilainya, yaitu a, b1, b2 dan b3, persamaan tersebut dapat dinyatakan 
dalam persamaan matriks sebagai berikut:

A

$=\left|\begin{array}{cccc}N & \Sigma X_{1} & \Sigma X_{2} & \Sigma X_{2} \\ \Sigma X_{1} & \Sigma\left(X_{1} \cdot X_{1}\right) & \Sigma\left(X_{1} \cdot X_{2}\right) & \Sigma\left(X_{1} \cdot X_{3}\right) \\ \Sigma X_{2} & \Sigma\left(X_{2} \cdot X_{1}\right) & \Sigma\left(X_{2} \cdot X_{2}\right) & \Sigma\left(X_{2} \cdot X_{3}\right) \\ \Sigma X_{3} & \Sigma\left(X_{3} \cdot X_{1}\right) & \Sigma\left(X_{3} \cdot X_{2}\right) & \Sigma\left(X_{3} \cdot X_{3}\right)\end{array}\right|$

$A 0$

$=\left|\begin{array}{cccc}\Sigma(\mathrm{Y}) & \Sigma X_{1} & \Sigma X_{2} & \Sigma X_{2} \\ \Sigma\left(X_{1} \cdot Y\right) & \Sigma\left(X_{1} \cdot X_{1}\right) & \Sigma\left(X_{1} \cdot X_{2}\right) & \Sigma\left(X_{1} \cdot X_{3}\right) \\ \Sigma\left(X_{2} \cdot Y\right) & \Sigma\left(X_{2} \cdot X_{1}\right) & \Sigma\left(X_{2} \cdot X_{2}\right) & \Sigma\left(X_{2} \cdot X_{3}\right) \\ \Sigma\left(X_{3} \cdot Y\right) & \Sigma\left(X_{3} \cdot X_{1}\right) & \Sigma\left(X_{3} \cdot X_{2}\right) & \Sigma\left(X_{3} \cdot X_{3}\right)\end{array}\right|$

$A 1$

$=\left|\begin{array}{cccc}N & \Sigma(Y) & \Sigma X_{2} & \Sigma X_{2} \\ \Sigma X_{1} & \Sigma\left(X_{1} \cdot Y\right) & \Sigma\left(X_{1} \cdot X_{2}\right) & \Sigma\left(X_{1} \cdot X_{3}\right) \\ \Sigma X_{2} & \Sigma\left(X_{2} \cdot Y\right) & \Sigma\left(X_{2} \cdot X_{2}\right) & \Sigma\left(X_{2} \cdot X_{3}\right) \\ \Sigma X_{3} & \Sigma\left(X_{3} \cdot Y\right) & \Sigma\left(X_{3} \cdot X_{2}\right) & \Sigma\left(X_{3} \cdot X_{3}\right)\end{array}\right|$

A2

$=\left|\begin{array}{cccc}N & \Sigma X_{1} & \Sigma(Y) & \Sigma X_{2} \\ \Sigma X_{1} & \Sigma\left(X_{1} \cdot X_{1}\right) & \Sigma\left(X_{1} \cdot Y\right) & \Sigma\left(X_{1} \cdot X_{3}\right) \\ \Sigma X_{2} & \Sigma\left(X_{2} \cdot X_{1}\right) & \Sigma\left(X_{2} \cdot Y\right) & \Sigma\left(X_{2} \cdot X_{3}\right) \\ \Sigma X_{3} & \Sigma\left(X_{3} \cdot X_{1}\right) & \Sigma\left(X_{3} \cdot Y\right) & \Sigma\left(X_{3} \cdot X_{3}\right)\end{array}\right|$

$A 3$

$=\left|\begin{array}{cccc}N & \Sigma X_{1} & \Sigma X_{2} & \Sigma(Y) \\ \Sigma X_{1} & \Sigma\left(X_{1} \cdot X_{1}\right) & \Sigma\left(X_{1} \cdot X_{2}\right) & \Sigma\left(X_{1} \cdot Y\right) \\ \Sigma X_{2} & \Sigma\left(X_{2} \cdot X_{1}\right) & \Sigma\left(X_{2} \cdot X_{2}\right) & \Sigma\left(X_{2} \cdot Y\right) \\ \Sigma X_{3} & \Sigma\left(X_{3} \cdot X_{1}\right) & \Sigma\left(X_{3} \cdot X_{2}\right) & \Sigma\left(X_{3} \cdot Y\right)\end{array}\right|$

Kemudian dapat dilakukan perhitungan untuk determinasi matriks A, A0, A1, A2 dan A3 sebagai berikut:

$\begin{array}{ll}\operatorname{Det}(\mathrm{A}) & N \sum\left(X_{1} X_{1}\right) \sum\left(X_{2} X_{2}\right) \sum\left(X_{3} X_{3}\right)+N \sum( \\ = & \left.X_{1} X_{2}\right) \sum\left(X_{2} X_{3}\right) \sum\left(X_{3} X_{1}\right)+N \sum\left(X_{1} X_{3}\right. \\ & \sum\left(X_{2} X_{1}\right) \sum\left(X_{3} X_{2}\right)+\sum X_{1} \sum X_{1} \\ & \sum\left(X_{2} X_{3}\right) \sum\left(X_{3} X_{2}\right)+\sum X_{1} \sum\left(X_{1} X_{2}\right) \\ & \sum X_{2} \sum\left(X_{3} X_{3}\right)+\sum X_{1} \sum\left(X_{1} X_{3}\right) \\ & \sum\left(X_{2} X_{2}\right) \sum X_{3}+\sum X_{2} \sum X_{1} \sum\left(X_{2} X_{1}\right) \\ & \sum\left(X_{3} X_{3}\right)+\sum X_{2} \sum\left(X_{1} X_{1}\right) \sum\left(X_{2} X_{3}\right) \\ & \sum X_{3}+\sum X_{2} \sum\left(X_{1} X_{3}\right) \sum X_{2} \sum\left(X_{3} X_{1}\right) \\ & +\sum X_{3} \sum X_{1} \sum\left(X_{2} X_{2}\right) \sum\left(X_{3} X_{1}\right)+ \\ & \sum X_{3} \sum\left(X_{1} X_{1}\right) \sum X_{2} \sum\left(X_{3} X_{2}\right)+\sum X_{3} \\ & \sum\left(X_{1} X_{2}\right) \sum\left(X_{2} X_{1}\right) \sum X_{3}- \\ & N \sum\left(X_{1} X_{1}\right) \sum\left(X_{2} X_{3}\right) \sum\left(X_{3} X_{2}\right)- \\ & N \sum\left(X_{1} X_{2}\right) \sum\left(X_{2} X_{1}\right) \sum\left(X_{3} X_{3}\right)- \\ & N \sum\left(X_{1} X_{3}\right) \sum\left(X_{2} X_{2}\right) \sum\left(X_{3} X_{1}\right)-\end{array}$

$\sum X_{1} \sum X_{1} \sum\left(X_{2} X_{2}\right) \sum\left(X_{3} X_{3}\right)-\sum X_{1}$ $\sum\left(X_{1} X_{2}\right) \sum\left(X_{2} X_{3}\right) \sum X_{3}$ $\sum X_{1} \sum\left(X_{1} X_{3}\right) \sum X_{2} \sum\left(X_{3} X_{2}\right)-$ $\sum X_{2} \sum X_{1} \sum\left(X_{2} X_{3}\right) \sum\left(X_{3} X_{1}\right)-$ $\sum X_{2} \sum\left(X_{1} X_{1}\right) \sum X_{2} \sum\left(X_{3} X_{3}\right)-\sum X_{2}$ $\sum\left(X_{1} X_{3}\right) \sum\left(X_{2} X_{1}\right) \sum X_{3}-\sum X_{3}$ $\sum X_{1} \sum\left(X_{2} X_{1}\right) \sum\left(X_{3} X_{2}\right)-$ $\sum X_{3} \sum\left(X_{1} X_{1}\right) \sum\left(X_{2} X_{2}\right) \sum X_{3}$ $\sum X_{3} \sum\left(X_{1} X_{2}\right) \sum X_{2} \sum\left(X_{3} X_{1}\right)$

Dengan cara yang sama seperti menghitung $\operatorname{Det}(\mathrm{A})$, dapat diperoleh pula $\operatorname{Det}(\mathrm{A} 0), \operatorname{Det}(\mathrm{A} 1), \operatorname{Det}(\mathrm{A} 2) \operatorname{dan} \operatorname{Det}(\mathrm{A} 3)$. Nilai a, b1, b2 dan b3 diperoleh dengan cara seperti berikut:

$$
\begin{aligned}
& a=\frac{\operatorname{Det}(A 0)}{\operatorname{Det}(A)} \\
& b 1=\frac{\operatorname{Det}(A 1)}{\operatorname{Det}(A)} \\
& b 2=\frac{\operatorname{Det}(A 2)}{\operatorname{Det}(A)}
\end{aligned}
$$

$b 3=\frac{\operatorname{Det}(A 3)}{\operatorname{Det}(A)}$

\section{Pengukuran Tingkat Kesalahan}

Keakuratan sebuah peramalan adalah aspek penting dari peramalan, sehingga peramal ingin memperkecil kesalahan yang terjadi pada peramalan. Menurut William J. Stevenson dan Sum Chee Chuong bahwa ada tiga ukuran kesalahan yang digunakan untuk merangkum kesalahan historis yaitu mean absolute deviation (MAD), mean squared error (MSE), dan mean absolute percent error (MAPE). MAD adalah rata-rata kesalahan absolut. Dalam MAD, kesalahan dengan arah positif atau negatif yang diukur hanya besar kesalahan secara absolut [11]. Perhitungan nilai MAD digunakan cara seperti berikut:

$$
M A D=\frac{\text { aktual }_{t-\text { ramalan }_{t}}}{n}
$$




\section{Padi}

Padi (Oryza Sativa) merupakan salah satu tananman budidaya terpenting dalam peradapan. Padi adalah tanaman yang banyak dibudidayakan didaerah tropis seperti Indonesia. Menurut Balai Besar Penelitian Tanaman Padi, umur padi antara 110 hari sampai 150 hari tergantung dengan varietas padi yang ditanam. Padi merupakan tanaman yang memerlukan air untuk pertumbuhannya. Ketersedian air baik itu dari air irigasi maupun air hujan sangan penting bagi pertumbuhan dan hasil dari tanaman padi. Pada tanaman padi terdapat tiga fase pertumbuhan, yaitu fase vegetatif( 0 - 60 hari), fase generatif (60 - 90 hari), dan fase pemasakan ( 90 - 120 hari). Kebutuhan air pada ketiga fase tersebut bervariasi. Selain itu terdapat beberapa faktor yang mempengaruhi pertumbuhan padi diantaranya, varietas, pupuk, serangan hama maupun yang lainnya.

\section{PHP}

PHP kepanjangan dari Hypertext Preprocessor yaitu bahasa pemrograman web server-side yang bersifat open source. PHP merupakan scriptyang terintegrasi dengan HTML dan berada pada server (server side HTML embedded scripting). Bahasa pemrograman PHP adalah salah satu bahasa pemrograman untuk aplikasi web yang terkenal.

Selain itu, PHP merupakan bahasa pemrograman yang sifatnya open source artinya bahasa ini boleh dipakai oleh siapapun juga tanpa harus mengeluarkan biaya untuk lisensinya. PHP juga boleh dimodifikasi sesuai kebutuhan penggunanya. Bahasa pemrograman ini dieksekusi oleh web server, maka tidak dibutuhkan compiler khusus untuk editor PHP [12].

\section{MySQL}

MySQL merupakan sebuah perangkat lunak sistem manajemen basis data SQL / DBMS (Database Management System) yang multithread, multiuser dan sekitar 6 juta instalasi diseluruh indonesia. Didistribusikan secara gratis dibawah lisensi GPL (General Public License). Dimana setiap orang bebas untuk menggunakan MySQL, namun tidak boleh dijadikan produk turunan yang bersifat komersial [12].

\section{METODE}

Alur penelitian yang digunakan adalah model SDLC (Software Development Life Cycle). Model SDLC yang dipakai dalam penelitian ini adalah Waterfall. Waterfall Model atau Classic Life Cicle merupakan model yang paling banyak dipakai dalam Software Enginnering. Menurut Bassil (2012) disebut waterfall karena tahap demi tahap yang harus dilalui menunggu selesainya tahap sebelumnya dan berjalan berurutan [13].

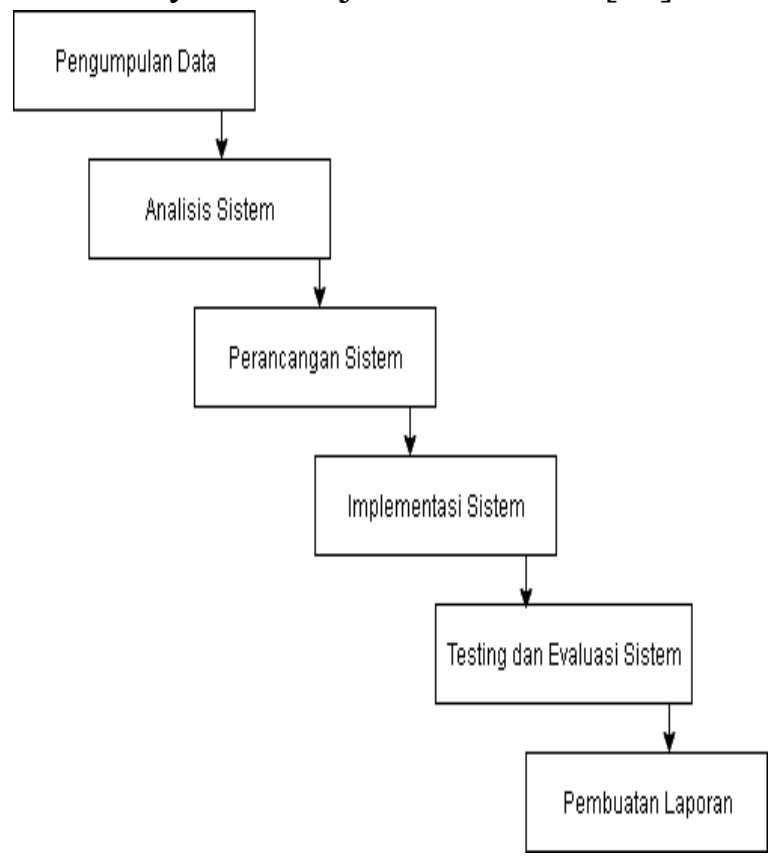

Gambar 1. Alur penelitian Waterfall

a. Pengumpulan Data

Pada tahap penelitian ini penyusun melakukkan analisa kebutuhan penelitian. Dalam tahap ini terdapat dua cara dalam 
mendapatkan data kebutuhan penelitian, yaitu wawancara dan studi pustaka.

\section{b. Pengumpulan Data}

Sistem ini dibuat untuk memprediksi produksi/panen padi di Kabupaten Bantul dengan menggunakan variabel input berupa faktor - faktor yang mempengaruhi produksi padi yaitu, luas panen, curah hujan, dan serangan hama pada padi. Prediksi ini dilakukan dengan menggunakan metode regresi linear berganda. Sistem ini menggunakan format webview yang sederhana sehingga memudahkan pengguna dalam menjalankannya.

- Analisis Kebutuhan Fungsional

- Admin harus melakukan login untuk melakukan proses pengolahan data dan prediksi.

- Sistem akan menampilkan data padi yang telah diinputkan.

- Sistem dapat melakukan prediksi dengan memasukan beberapa faktor yang diperlukan.

- Analisis Kebutuhan Non Fungsional

o Komputer/Laptop dengan spesifikasi minimum:

o Sistem Operasi: Windows/Linux

○ DBMS: MySQL

○ Script Engine: PHP

o Web browser: Chrome/Firefox

c. Perancangan Sistem

- Perancangan Database

Perancangan database digunakan untuk merancang penyimpanan data dari inputan yang dimasukan pada Sistem Prediksi Hasil Panen padi di Kabupaten Bantul. Pada penelitian ini perancangan database menggunakan ERD. Dalam penelitian ini terdapat 3 entitas yaitu, Admin, tabeldata, dan tabelhasilpanen. Selain itu terdapat satu relasi yang ada yaitu, menginputkan. Untuk penjelas lebih lanjut pada gambar dibawah ini.

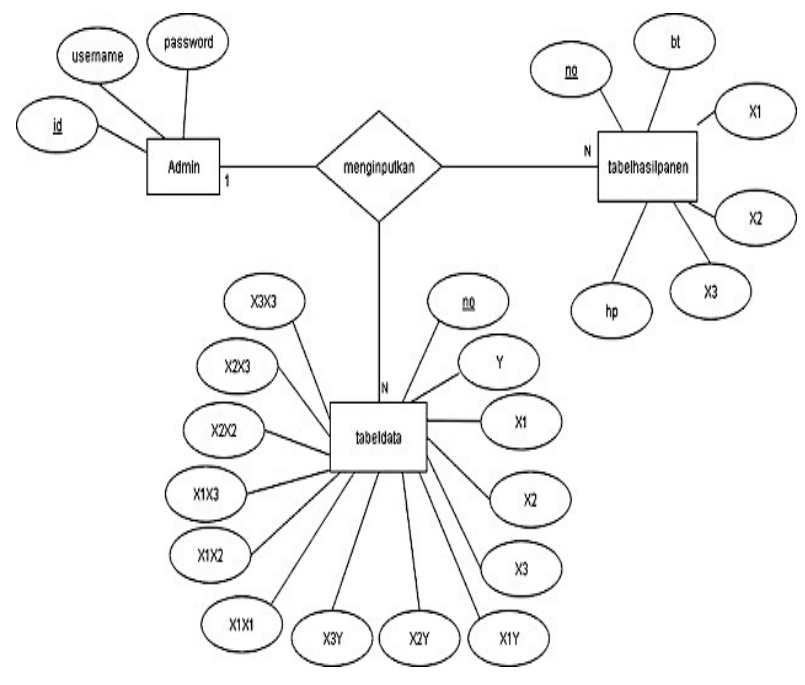

Gambar 2. ERD rancangan database Keterangan:

1. Entitas : Admin, Tabelhasilpanen, dan Tabeldata

2. Attribut Entitas :

a. Entitas Admin memiliki attribut : id, username, password

b. Entitas Tabeldata memiliki attribut : no, Y, X1, X2, X3, X1Y, X2Y, $\mathrm{X} 3 \mathrm{Y}, \mathrm{X} 1 \mathrm{X} 1, \mathrm{X} 1 \mathrm{X} 2, \mathrm{X} 1 \mathrm{X} 3, \mathrm{X} 2 \mathrm{X} 2$, $\mathrm{X} 2 \mathrm{X} 3, \mathrm{X} 3 \mathrm{X} 3$.

c. Entitas Tabelhasipanen memiliki attribut: no, bt, X1, X2, X3, hp.

3. Relasi : menginputkan

4. Primary Key

a. Entitas Admin memiliki Primary key: id.

b. Entitas tabeldata memiliki Primary key: no.

c. Entitas tabelhasilpanen memiliki Primary key : no.

- Perancangan Aplikasi web

Perancangan untuk aplikasi web prediksi produksi padi di kabupaten Bantul digunakan salah satu rancangan dalam UML (Unified Modeling Language) yaitu Activity diagram yang mewakili proses kegiatan dari pengguna yaitu admin dan sistem.

1. Activity diagram Login 


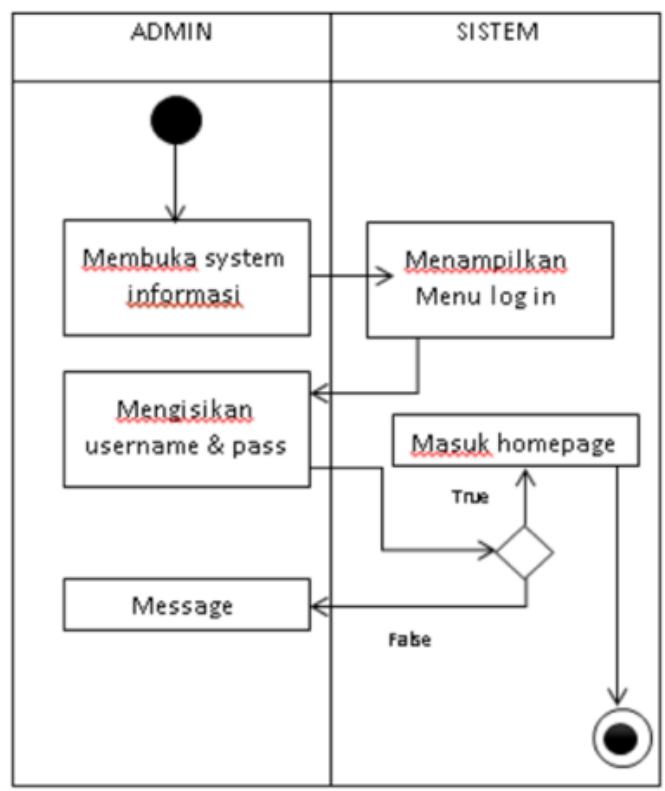

Gambar 3. Activity diagram login

Dalam activity diagram login diatas admin harus membuka sistem dan memasukan username dan password untuk bisa masuk ke homepage/dashboard. Jika username dan password salah maka akan muncul peringatan.

2. Activity diagram input/edit data

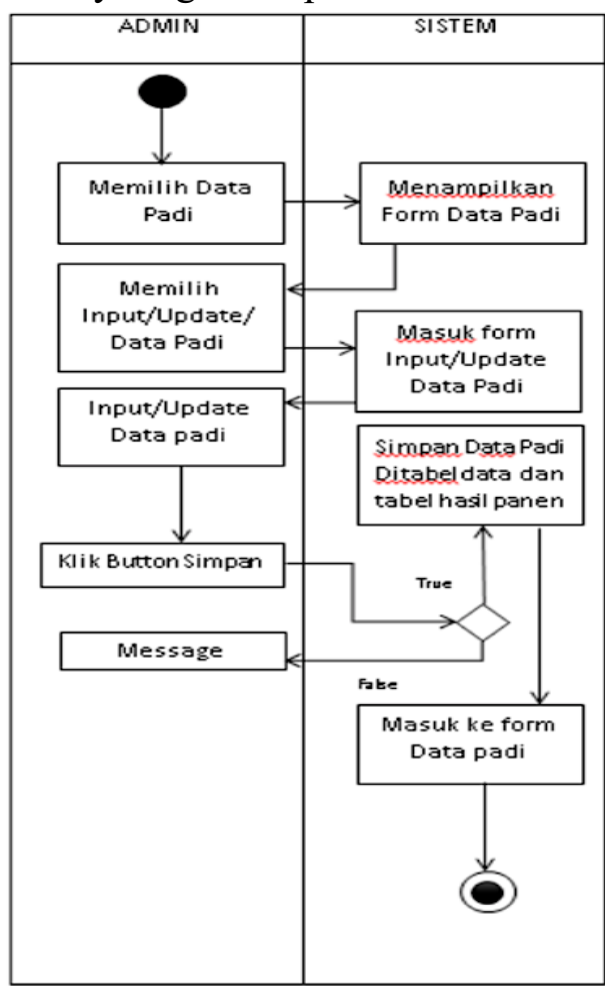

Gambar 4. Activity diagram input/edit data

Dalam activity diagram diatas admin masuk kedalam aplikasi kemudian memilih menu data padi. Setelah itu admin dapat memilih input data atau update data. Setelah itu admin mengisikan data. Setelah selesai admin mengeklik button input/update. Jika benar maka data akan masuk ke database dan jika salah maka akan muncul pesan.

\section{Activity diagram prediksi}

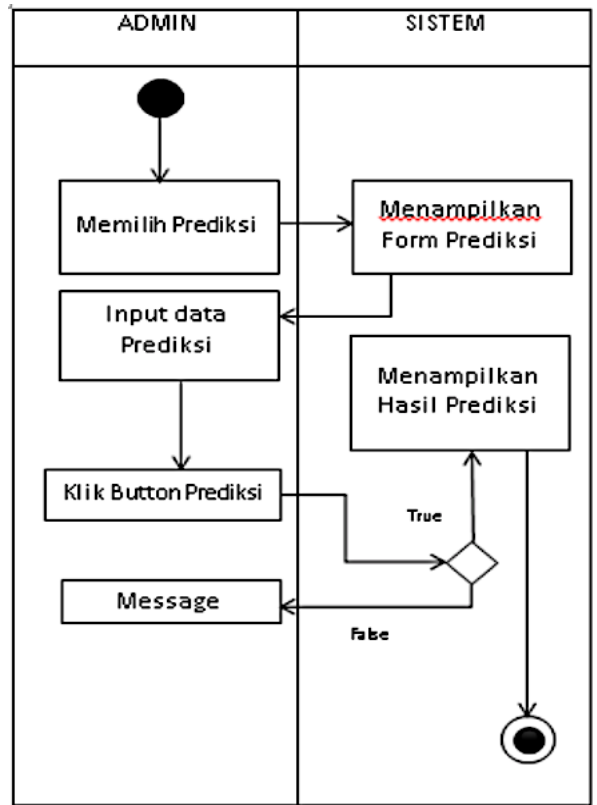

Gambar 5. Activity diagram prediksi

Dalam aktivity diagram diatas admin harus memilih menu prediksi. Setelah itu admin menginputkan faktor - faktor prediksi. Setelah semua terisi dan benar, kemudia admin mengeklik button preiksi. Setelah itu ada pernyataan. Jika benar maka hasil prediksi akan keluar dan jika salah maka akan keluar pesan.

\section{d. Implementasi Sistem}

Tahap implementasi menerjemahkan desain sebelumnya menjadi sistem prediksi hasil panen padi di Kabupaten Bantul. Pada tahap ini terdiri dari tahap pengkodingan atau pembuatan program yang disesuaikan dengan tujuan awal yaitu : code program dan 
penerapan database. Pada tahap pembuatan kode program atau pengkodingan menggunakan bahasa pemrograman PHP. Pada penyusunan database menggunakan MySQL dengan web server local.

\section{e. Evaluasi dan Testing}

Tahap testing atau tahap pengujian sistem aplikasi prediksi hasil panen padi dengan metode Regresi Linear Berganda ini dilakukan dengan melakukan pengujian secara fungsional maupun validitas. Dalam pengujian fungsional dilakukan dengan menguji apakan perangkat lunak berfungsi dengan benar atau belum. Jika belum maka akan dicari masalah yang ditemukan. Sedangkan untuk pengujian validitas adalah pengujian untuk mengukur tingkat kesalahan nilai prediksi. Jika nilai kesalahan yang didapat kecil, maka dapat hasil prediksi akan baik.

\section{f. Pembuatan Laporan}

Selama kegiatan dalam penelitian sementara berjalan, maka penulis juga melakukan penyusunan laporan. Penyusunan laporan dimulai dari pendahuluan, landasan teori, metodologi penelitian, Implementasi dan pembahasan, penutup, dan daftar pustaka.

\section{HASIL}

\section{Prediksi hasil panen padi}

Pada penelitian ini metode Regresi Linear Berganda digunakan untuk melakukan prediksi hasil panen padi di Kabupaten Bantul. Untuk menentukan bobot variabel, peneliti menggunakan data hasil panen yang dipengaruhi oleh bebrapa faktor yaitu luas panen, curah hujan, dan hama. Ada banyak faktor yang mempengaruhi hasil panen padi, namun pada penelitian ini hanya membatasi 3 faktor saja, meliputi hasil panen padi, curah hujan dan hama yang menyerang tanaman padi.

Dalam penelitian data diambil dari tahun 2009 sampai dengan 2017. Dalam setiap tahunnya tanaman padi dapat ditanam selama 3 - 4 kali sehingga terdapat 3 periode dalam satu tahun.

Luas panen adalah salah satu faktor yang digunakan untuk memprediksi hasil panen padi. Luas lahan sawah di Bantul yang mencapai 15000 ha ini seharusnya dimanfaatkan oleh petani untuk meningkatkan hasil panen padi. Semakin luas lahan yang ditanami maka semakin banyak pula presentase hasil panen padi yang di dapatkan. Luas panen yang besar tentu saja akan menghasilkan hasil panen yang banyak jika tidak ada faktor penyebab berkurangnya panen seperti hama, curah hujan dan lainnya. Oleh karena itu luas lahan panen dijadikan faktor penentu prediksi hasli panen padi.

Selain faktor luas lahan panen, terdapat faktor yang kedua yaitu curah hujan. Padi adalah tanaman air, namun bukan hidupnya didalam air.Artinya padi memerlukan air yang cukup untuk proses hidupnya. Curah hujan adalah salah satu penyedia air bagi tanaman padi.

Tanaman padi dapat hidup baik di daerah yang berhawa panas dan banyak mengandung uap air. Curah hujan yang bagus dan optimal akan meningkatkan produksi tanaman padi menjadi semakin banyak. Sedangkan jika curah hujan berlebihan bisa berakibat buruk bagi tanaman, misalnya banjir dan memunculkan banyak hama yang menyerang. Selain itu jika curah hujan kurang maka persedian air pada tanaman padi menjadi berkurang sehingga padi tidak subur dan bisa mati sehingga mengakibatkan penurunan produksi padi.

Curah hujan dibagi menjadi 5 (lima) golongan yaitu: 
1. Tinggi ( $\geq 350 \mathrm{~mm}$ perbulan ): -30 Hasil panen dengan curah hujan tinggi akan berkurang $30 \%$ dari rata - rata hasil panen maksimal.

2. Baik ( $\leq 150 / \geq 250 \mathrm{~mm}$ perbulan ): 10 . Hasil panen dengan curah hujan baik akan bertambah $10 \%$ dari rata - rata hasil panen maksimal.

3. Optimal ( $\geq 200 \mathrm{~mm}$ perbulan ): 20 . Hasil panen dengan curah hujan optimal akan bertambah $20 \%$ dari rata - rata hasil panen maksimal.

4. Normal ( $\geq 100 \mathrm{~mm}$ perbulan ): 0. Hasil panen dengan curah hujan normal akan bernilai $0 \%$ dari rata - rata hasil panen maksimal.

5. Kurang ( $\leq 100 \mathrm{~mm}$ perbulan ): -20 . Hasil panen dengan curah hujan kurang akan berkurang $20 \%$ dari rata - rata hasil panen maksimal.

Selain dua faktor diatas terdapat satu faktor lagi yang sangat mempengaruhi hasil panen padi yaitu hama. Hama adalah organisme yang merusak tanaman yang dapat menyerang pada akar, daun, batang, dan bagian tanaman lainnya, sehingga tanaman tidak dapat tumbuh dengan sempurna atau mati. Pada tanaman padi hama sangatlah banyak ditemui dan meresahkan bagi petani. Hama dapat mengakibatkan gagal panen pada tanaman padi sehingga sangat berpengaruh dalam prediksi hasil panen padi ini.

Terdapat berbagai macam hama yang sering menyerang padi, diantaranya wereng, tikus, belalang, keong, burung dan jenis hama lainnya. Hama yang paling sering menyerang tanaman padi adalah hama wereng, wereng ini akan menghisap cairan yang ada pada tanaman padi yang mengakibatkan tanaman menjadi kering ataupun pertumbuhannya menjadi kerdil. Dalam penelitian ini hama dijadikan faktor prediksi dengan menggunakan rata - rata serang dalam setiap priode misalnya, $10 \%$ dari luas lahan yang diserang.

\section{Algoritma Regresi linear berganda}

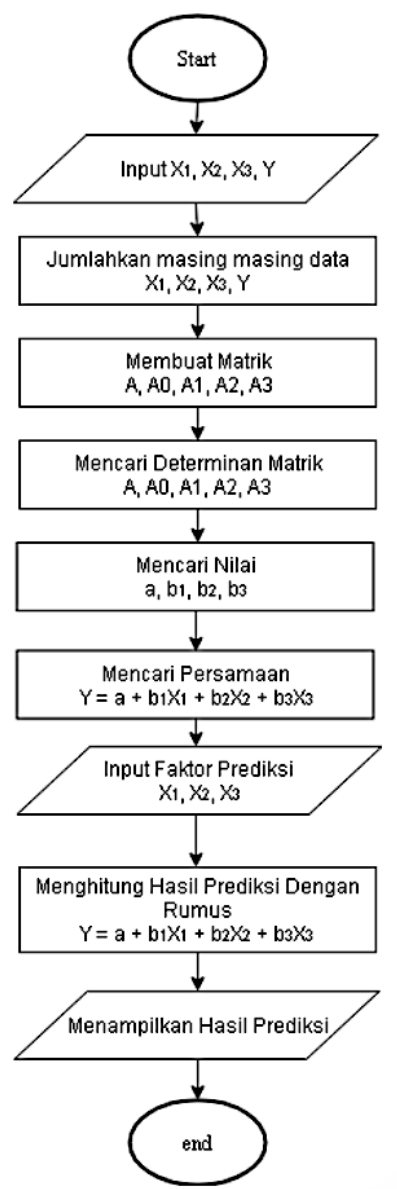

Gambar 6. Flowchart algoritam Regresi linear berganda

Pada tahap implementasi aplikasi web akan ditambahkan fitur untuk prediksi menggunakan aturan sesuai flowchart pada gambar 6 diatas. Penjelasan tahapan tersebut adalah sebagai berikut:

1. Setelah inisialisasi start dilanjutkan langkah kedua adalah memasukan variabel dependen dan independen.

2. Langkah ketiga adalah menjumlahkan data yang telah dimasukan sesuai dengan kolom masing - masing.

3. Setelah itu adalah pembuatan matrik $A$, A0, A1, A2, A3 dari data yang telah dijumlahkan sebelumnya. 
4. Setelah matrik dibuat, langkah selanjutnya adalah menentukan determinan dari kelima matrik tersebut dengan metode sarrus.

5. Setelah determinan di dapatkan maka selanjutnya adalah mencari nilai dari a, b1, b2, b3 yang digunakan untuk mencari persamaan Regresi Linear Berganda.

6. Langkah selanjutnya adalah memasukannya menjadi sebuah persamaan Regresi Linear Berganda. Setelah itu bisa dilakukakan sebuah prediksi.

7. Untuk melakukan sebuah prediksi tentu saja diperlukan inputan variabel independen yang akan diprediksi.

8. Setelah di masukan faktor/variabelnya, maka langkah selanjutnya adalah memasukan dan menghitungnya dengan persamaan yang telah di dapatkan.

9. Setelah itu dapat ditampilkan hasil prediksi dan selesai.

\section{Persamaan Regresi linear berganda}

Dalam melakukan prediksi tentu saja memerlukan data yang digunakan sebagai data untuk menentukan persamaan Regresi Linear Berganda. Data hasil panen dan ketiga faktornya diambil dari tahun 2009 sampai tahun 2017.

Tabel 1. Data Hasil Panen tahun 2009 - 2017

\begin{tabular}{|c|c|c|c|c|}
\hline $\begin{array}{l}\mathbf{N} \\
\mathbf{0}\end{array}$ & $\begin{array}{c}\text { Luas } \\
\text { Panen } \\
\text { (X1) }\end{array}$ & $\begin{array}{c}\text { Curah } \\
\text { Hujan } \\
\text { (X2) }\end{array}$ & $\begin{array}{c}\text { Ham } \\
\mathbf{a} \\
\text { (X3) }\end{array}$ & $\begin{array}{c}\text { Hasil } \\
\text { Pane } \\
\text { n }\end{array}$ \\
\hline 1 & 14210 & Baik (10) & $\begin{array}{r}10,7 \\
\%\end{array}$ & 91862 \\
\hline 2 & 108 & $\begin{array}{l}\text { Kurang (- } \\
20)\end{array}$ & $\begin{array}{r}12,0 \\
\%\end{array}$ & 8244 \\
\hline 3 & 3185 & $\begin{array}{l}\text { Kurang (- } \\
20)\end{array}$ & $\begin{array}{r}11,9 \\
\%\end{array}$ & 22737 \\
\hline 4 & 12254 & Baik (10) & $5,9 \%$ & 81121 \\
\hline
\end{tabular}

\begin{tabular}{lllrl}
\hline 5 & 11851 & Kurang (- & $\begin{array}{r}75,0 \\
\text { 20) }\end{array}$ & 63034 \\
& & Baik (10) & $\begin{array}{r}14,5 \\
\%\end{array}$ & 46201 \\
& 6621 & & \\
\hline 7 & 13388 & Baik (10) & $7,5 \%$ & 87552 \\
\hline 8 & 12708 & Kurang (- & 23,7 & 77131 \\
& & $20)$ & $\%$ & \\
\hline 9 & 4603 & Baik (10) & 19,7 & 33321
\end{tabular}

\begin{tabular}{lllll}
\multicolumn{3}{c}{$\%$} \\
\hline 10 & 13355 & Baik (10) & $1,9 \%$ & 88343 \\
\hline 11 & 12291 & Optimal & $7,2 \%$ & 82286
\end{tabular}

\begin{tabular}{lllll}
\hline 12 & 4559 & Normal & $4,0 \%$ & 34635
\end{tabular}

\begin{tabular}{|c|c|c|c|c|}
\hline 13 & 13102 & Baik (10) & $\begin{array}{r}10,5 \\
\%\end{array}$ & 85337 \\
\hline 14 & 12393 & $\begin{array}{l}\text { Kurang (- } \\
20)\end{array}$ & $\begin{array}{r}30,8 \\
\%\end{array}$ & 74008 \\
\hline & $19^{\prime}$ & Normal & $5,5 \%$ & 001 \\
\hline
\end{tabular}

\begin{tabular}{lllll}
\hline 16 & 13596 & Baik (10) & 27,6 & 85263
\end{tabular}

\begin{tabular}{rrrrr} 
& & \multicolumn{3}{c}{$\%$} \\
\hline 17 & 11167 & Baik (10) & $7,9 \%$ & 74316 \\
\hline 18 & 5424 & Kurang (- & 27,5 & 33268
\end{tabular}

\begin{tabular}{rrlrr} 
& & $20)$ & $\%$ & \\
\hline 19 & 13006 & Baik (10) & $1,0 \%$ & 86431 \\
\hline 20 & 11169 & Kurang (- & 11,5 & 70152
\end{tabular}

\begin{tabular}{rrrrr} 
& $20)$ & $\%$ & \\
\hline 21 & 5467 & Optimal & $3,0 \%$ & 42561
\end{tabular}
(20)

\begin{tabular}{rrrrr}
\hline 22 & 12149 & Baik (10) & $\begin{array}{r}26,0 \\
\%\end{array}$ & 76962 \\
& & & \\
\hline
\end{tabular}

$23 \quad 12338$ Kurang (- $55,0 \quad 69432$

\begin{tabular}{rrrrr} 
& $20)$ & $\%$ & \\
\hline 24 & 5522 & Normal & 24,1 & 36812
\end{tabular}

$\%$

\begin{tabular}{lllll}
\hline 25 & 13088 & Optimal & $1,0 \%$ & 88102
\end{tabular} (20)

\begin{tabular}{lllrl}
\hline 26 & 12292 & Kurang (- & 60,9 & 68126 \\
& & $20)$ & $\%$ & \\
\hline 27 & 4645 & Kurang (- & 40,5 & 26374 \\
& & $20)$ & $\%$ & \\
\hline
\end{tabular}


Selanjutnya data dimasukan ke dalam database pada tabeldata maka akan didapatkan data prediksi seperti gambar 7 dibawah ini:

\begin{tabular}{|c|c|c|c|c|c|c|c|c|c|c|c|c|c|}
\hline & & $x 1$ & X2 & x3 & XIY & $\mathrm{X} 2 \mathrm{Y}$ & XYY & $1 \times 1$ & $1 \times 2$ & $x 1 \times 3$ & $\times 2 \times 2$ & $62 x$ & ( \\
\hline 1 & 91862 & 14210 & 10 & -10 & 1305359020 & 918620 & -918620 & 201924100 & \begin{tabular}{|l|l|} 
& 142100 \\
\end{tabular} & -142100 & 100 & -100 & 100 \\
\hline & 68244 & 10863 & -20 & -10 & $7413345 / 2$ & -1364880 & -682440 & 118004769 & -217260 & -108630 & 400 & 200 & 100 \\
\hline 3 & 22737 & 185 & -20 & -20 & & 740 & -454740 & & 700 & 63700 & 400 & 400 & 400 \\
\hline 4 & 81121 & 12254 & 10 & -10 & 994056734 & 811210 & -811210 & 150160516 & 122540 & -122540 & 100 & -100 & 100 \\
\hline 5 & 63034 & 11851 & -20 & 70 & 7015934 & -1260680 & -4412380 & 140446201 & -237020 & -829570 & 400 & 1400 & 4900 \\
\hline 6 & 46201 & 621 & 10 & -20 & 15896821 & 462010 & -924020 & 837641 & 5210 & -132420 & 100 & -200 & 400 \\
\hline 7 & 87552 & 13388 & 10 & -10 & $\mid 1172146176$ & 875520 & -875520 & 179238544 & 33880 & -133880 & 100 & -100 & 100 \\
\hline 8 & 77131 & 12708 & -20 & -20 & 980180748 & -1542620 & -1542620 & 93264 & -254160 & -254160 & 400 & 40 & 400 \\
\hline 9 & 33321 & 4603 & 0 & -20 & 153376563 & 0 & -666420 & 21187609 & 0 & -92060 & & 0 & 400 \\
\hline 10 & 88343 & 13355 & 0 & 5 & 1179820765 & 0 & 715 & 178356025 & & bor/t5 & & 0 & 25 \\
\hline 11 & 82286 & 12291 & 0 & 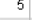 & 10 & & 430 & 15 & 0 & 614 & & 0 & 25 \\
\hline 12 & 34635 & 4559 & 0 & -10 & 157900965 & 0 & -346350 & 20784481 & 0 & -45590 & 0 & 0 & 100 \\
\hline 13 & 85337 & 13102 & 10 & -10 & $\mid 1118085374$ & 853370 & -853370 & 171662404 & 31020 & -131020 & 100 & -100 & 100 \\
\hline 14 & 74008 & 12393 & -20 & -30 & 44 & -1480160 & -2220240 & 15358 & -247860 & -371790 & 400 & 600 & s \\
\hline 15 & 50019 & 7197 & 0 & -10 & 359986743 & 0 & -500190 & 51796809 & 0 & -71970 & 0 & 0 & 100 \\
\hline 16 & 85263 & 13596 & 10 & -30 & 1159235748 & 852630 & -2557890 & 184851216 & 135960 & -407880 & 100 & -300 & 900 \\
\hline II & 74316 & 11167 & 10 & -10 & . & 743160 & 43160 & 1247 & 11670 & 1110070 & 100 & -1000 & 700 \\
\hline 18 & 33268 & 5424 & -20 & -30 & 180445632 & -665360 & -998040 & 419776 & -108480 & -162720 & 400 & 600 & 900 \\
\hline 19 & 86431 & 13006 & 0 & 5 & |1124121586 & 0 & 432155 & 169156036 & 0 & 65030 & 0 & 0 & 25 \\
\hline 20 & 152 & 11169 & -20 & -10 & 88 & 040 & -801520 & 124746561 & -223380 & -111690 & 400 & 200 & 100 \\
\hline 21 & 425 & 67 & 0 & & & & 805 & 089 & & 335 & 0 & 0 & \\
\hline 22 & 76962 & 12149 & 10 & -30 & 5011338 & 769620 & -2308860 & 147598201 & 121490 & -364470 & 100 & -300 & 900 \\
\hline 23 & 69432 & 12338 & -20 & -50 & 6652016 & 388640 & 1600 & 152 & 6760 & -616900 & 400 & 000 & 2500 \\
\hline 24 & 8812 & 5522 & & 30 & & & -11 & & & 660 & & 0 & 300 \\
\hline 15 & 2 & 13088 & 10 & 5 & 115 & 20 & 510 & 744 & 130880 & 55440 & 100 & 50 & 25 \\
\hline 26 & 68126 & 292 & 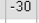 & -50 & 04792 & -2043780 & -340 & 151 & -368760 & -614600 & 900 & 1500 & 2500 \\
\hline & 26374 & 4645 & 20 & -45 & 77230 & 480 & -1 & 76025 & -92900 & 902 & 400 & 900 & 202 \\
\hline
\end{tabular}

Gambar 7. Tabeldata di database MySQL

Setelah data prediksi didapatkan maka langkah selanjutnya adalah menjumlahkan data tersebut berdasarkan kolom masing masing.

Tabel 2. Jumlah Data Prediksi

\begin{tabular}{cr}
\hline $\mathrm{X}$ & 1743630 \\
\hline $\mathrm{X} 1$ & 272443 \\
\hline $\mathrm{X} 2$ & -30 \\
\hline $\mathrm{X} 3$ & $-526,8$ \\
\hline $\mathrm{X} 1 \mathrm{Y}$ & 19633964784 \\
\hline $\mathrm{X} 2 \mathrm{Y}$ & 1175950 \\
\hline $\mathrm{X} 3 \mathrm{Y}$ & $-32327159,73$ \\
\hline $\mathrm{X} 1 \mathrm{X} 1$ & 3090737245 \\
\hline $\mathrm{X} 1 \mathrm{X} 2$ & -45930 \\
\hline $\mathrm{X} 1 \mathrm{X} 3$ & -54084828125 \\
\hline $\mathrm{X} 2 \mathrm{X} 2$ & 6300 \\
\hline $\mathrm{X} 2 \mathrm{X} 3$ & 5420 \\
\hline $\mathrm{X} 3 \mathrm{X} 3$ & 19791,32 \\
\hline
\end{tabular}

Setelah jumlah data per kolom di dapatkan maka akan dioleh untuk menentukan konstanta dan koefisien regresi dengan menggunakan determinan matrik A, A0, A1, A2, A3 sesuai dengan persamaan (5).

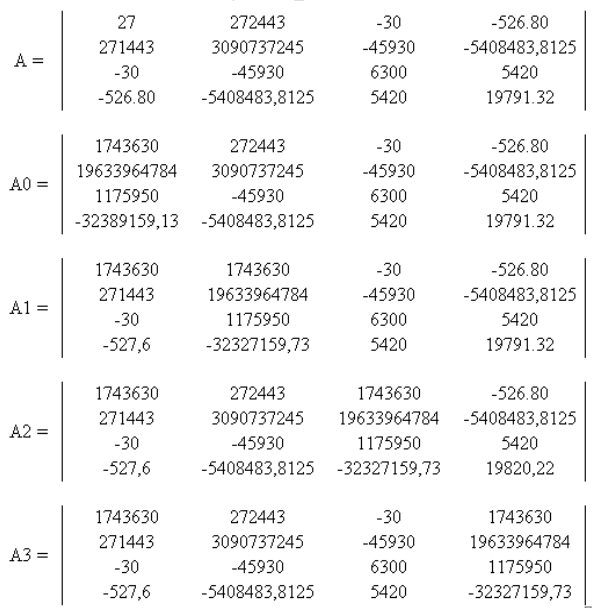

Gambar 8. Matrik Hasil Perhitungan Data Selanjutnya adalah menentukan determinan dari matrik tersebut dengan menggunakan metode sarrus sesuai dengan persamaan (6). Berikut ini hasil dari perhitungan determinan dari A, A0, A1, A2, A3

Tabel 3. Hasil determinan Matrix

\begin{tabular}{|c|c|}
\hline Det A & $3.0968729254509 \mathrm{E}+17$ \\
\hline Det & $2.572746211022 \mathrm{E}+21$ \\
\hline \multicolumn{2}{|l|}{ A0 } \\
\hline Det & $1.8362766703211 \mathrm{E}+18$ \\
\hline \multicolumn{2}{|l|}{ A1 } \\
\hline Det & $3.6630008687283 E+19$ \\
\hline \multicolumn{2}{|l|}{$\mathrm{A} 2$} \\
\hline Det & $5.4415182792801 \mathrm{E}+19$ \\
\hline
\end{tabular}

Dari nilai determinan yang telah di hitung maka nilai a, b1,b2, dan b3 dapat dicari dengan persamaan (7) sebagai berikut:

$$
\begin{aligned}
& a=\frac{2.572746211022 \mathrm{E}+21}{3.0968729254509 \mathrm{E}+17}=8307,561443282 \\
& b_{1}=\frac{1.8362766703211 \mathrm{E}+18}{3.0968729254509 \mathrm{E}+17}=5,9294543706657 \\
& b_{2}=\frac{3.6630008687283 \mathrm{E}+19}{3.0968729254509 \mathrm{E}+17}
\end{aligned}
$$

118,28063200866

$b_{3}=\frac{5.4415182792801 \mathrm{E}+19}{3.0968729254509 \mathrm{E}+17}=175,71009241484$ 
Setelah nilai dari a, b1, b2, dan b3 telah dihitung maka dapat diperoleh persamaan regresi linear berganda untuk data hasil panen padi tersebut yaitu $\mathrm{Y}=8307,561443282+$ $5,9294543706657 x_{1}+118,28063200866 x_{2}+$ $175,71009241484 x_{3}$

\section{Pengujian hasil prediksi}

Untuk meningkatkan hasil prediksi panen padi tentu diperlukan pengujian hasil panen. Pengujian ini dilakukakan untuk menentukan error dari hasil prediksi hasil panen. Semakin kecil error yang didapatkan maka akan semakin tepat juga hasil prediksi. Untuk melakukan pengujian ini peneliti menggunakan mean absolute deviation (MAD). MAD adalah rata-rata kesalahan absolut, MSE adalah kesalahan kuadrat.Dalam MAD, kesalahan dengan arah positif atau negatif yang diukur hanya besar kesalahan secara absolut.

Rumus untuk mencari rata - rata kesalahan absolut ini sesuai dengan persamaan (8) seperti contoh data berikut ini:

Data ke 2 pada tabel data yaitu :

\begin{tabular}{ll} 
Bulan Tanam & : Mei - Agustus 2009 \\
Luas lahan Panen & \multicolumn{1}{c}{$: 10863$ ha } \\
Curah hujan & $:$ Kurang $(-20)$ \\
Hama & $: 12 \%(-12)$ \\
Hasil Panen & $: 68244$ ton \\
Hasil Prediksi & $: 68245,09$ ton
\end{tabular}

$M A D=\frac{68244-6245,90}{27}=0,040$

Setelah dilakukan pengujian kesalahan rata - rata error telah didapatkan error yang cukup kecil sehingga data hasil prediksinya hampir tepat. Untuk hasil kesalahan rata - rata eror absolut semua data dapat yaitu 0,101

\section{Implementasi di Aplikasi}

Untuk kode di program PHP bagian prediksi dituliskan seperti pada gambar 9 dibawah ini:

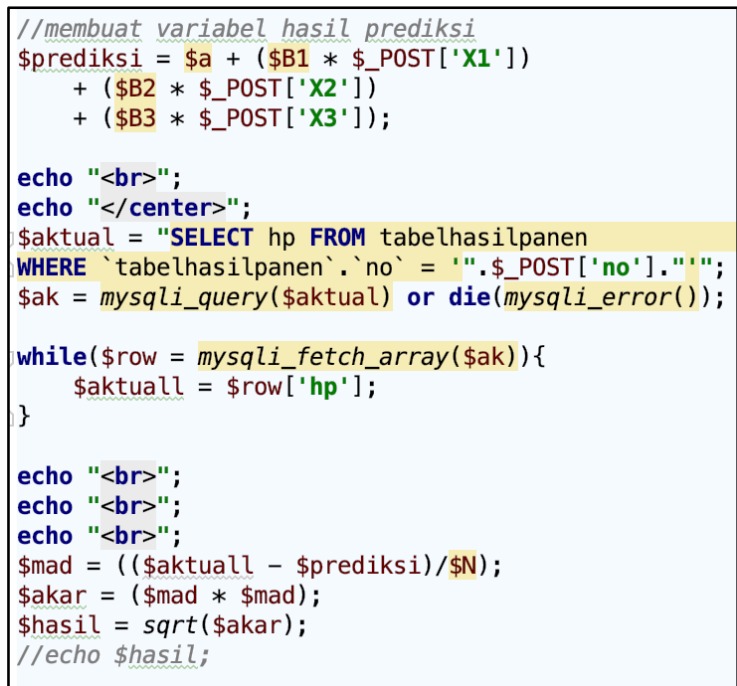

Gambar 9. Kode PHP prediksi

Data hasil produksi padi ditampilkan dalam aplikasi web seperti gambar 10 berikut:
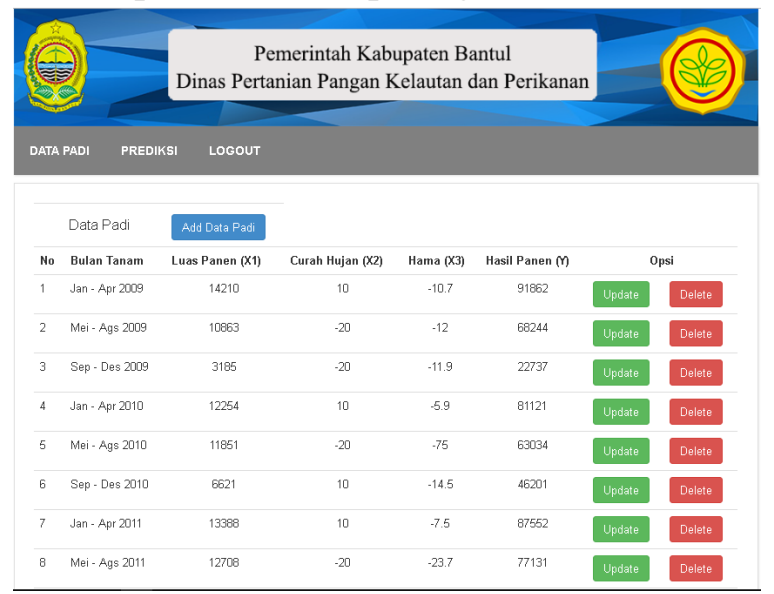

Gambar 10. Halaman data padi

Inti dari pembuatan aplikasi ini adalah
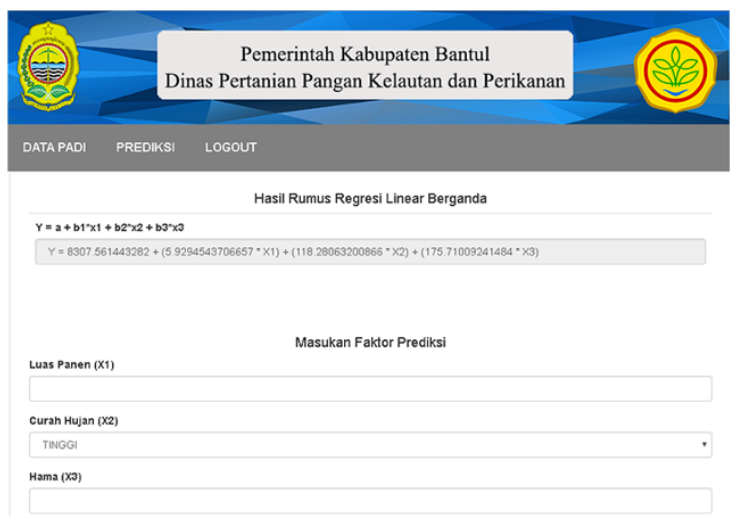
untuk memprediksi hasil panen padi. Gambar 11 dibawah ini adalah form web untuk melakukan prediksi.

Gambar 11. Halaman prediksi

Contohnya akan memprediksi hasil panen dengan luas lahan panen 10000 ha dengan curah hujan baik(10) dan jumlah hama yang menyerang sebesar $10 \%(-10)$. Sesuai perhitungan rumus yang telah diimplementasikan di PHP menghasilkan prediksi hasil panen sebesar 67027,81 ton seperti pada gambar 12 .

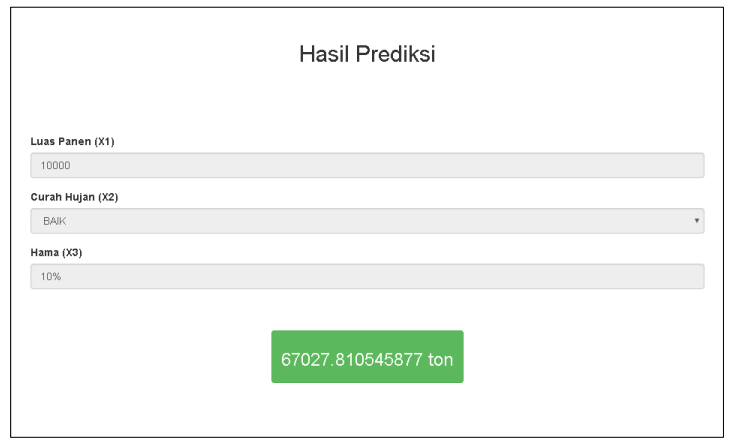

Gambar 12. Perhitungan hasil prediksi

\section{KESIMPULAN}

Berdasarkan pembahasan yang telah dilakukan sebelumnya, maka pada penelitian ini dapat diambil kesimpulan yaitu:

1. Penelitian ini menghasilkan sebuah aplikasi berbasis web untuk memprediksi produksi padi di Kabupaten Bantul dengan Algoritma Regresi Linear Berganda dengan memperhitungkan 3 variabel yang meliputi luas lahan panen, curah hujan, dan serangan hama yang dapat mempengaruhi produksi padi.

2. Persamaan Regresi Linear berganda yang didapatkan yaitu $\mathrm{Y}=8307,561443282+$ $5,9294543706657 x_{1}$

$118,28063200866 x_{2}$ $175,71009241484 x_{3}$

3. Melalui pengujian validitas dengan menggunakan metode MAD didapatkan hasil uji untuk prediksi produksi padi sebesar 0,101 sehingga untuk hasil prediksi dalam kategori sangat baik.

\section{DAFTAR PUSTAKA}

[1] M. Fathurahman and Haeruddin, "Pemodelan Regresi Linier untuk Data Deret Waktu," J. Eksponensial, pp. 3641, 2011.

[2] A. Romandoni, "Penerapan Metode Regresi Linear Berganda untuk Prediksi Hasil Panen Jagung," STMIK Sinar Nusantara, 2017.

[3] N. S. Utomo, "Aplikasi Prediksi Kelayakan Operasional Mesin Rivet Produksi Menggunakan Metode Regresi Linear Berganda (Studi Kasus: PT Pradana Indah Sejahtera)," Politeknik Negeri Batam, 2015.

[4] Farizal, A. Rachman, and H. Al Rasyid, "Model Peramalan Konsumsi Bahan Bakar Jenis Premium Di Indonesia Dengan Regresi Linier Berganda," J. Ilm. Tek. Ind., vol. 13, pp. 166-176, 2014.

[5] E. Turban, J. E. Aronson, and T.-P. Liang, Decicion Support Systems and Intelligent Systems, 1st ed. Andi Offset, 2005.

[6] D. T. Larose, Discovering Knowledge in Data: An Introduction to Data Mining, 1st ed. John Willey \& Sons. Inc, 2005.

[7] Herdianto, "Prediksi Kerusakan Motor Induksi Menggunakan Metode Jaringan Saraf Tiruan Backpropagation," Universitas Sumatera Utara, 2013.

[8] S. Makridakis, Metode dan Aplikasi Peramalan. Jakarta: Erlangga, 1993.

[9] Y. H. Ngumar, "Aplikasi Metode Numerik Dan Matrik Dalam Perhitungan Koefisien-Koefisien Regresi Linier Multiple Untuk," pp. 157-162, 2008.

[10]J. Supranto, Statistik: Teori dan Aplikasi, 1st ed. Jakarta: Erlangga, 2000.

[11] S. C. Stevenson, William J. Dan Choung, 
Manajemen Operasi, 9th ed. Jakarta: McGraw-Hill Education (Asia), 2014.

[12]Anhar, Panduan Menguasai PHP dan MySQL Secara Otodidak. Jakarta: Media Kita, 2010.

[13]B. Youseff, "A Simulation Model for the Waterfall Software Development Life Cycle," Int. J. Eng. Technol., vol. 2, 2012. 